\title{
High risk of adult asthma following severe wheeze in early life
}

\author{
Emma Goksör ${ }^{1 *}$, Bernt Alm¹, Mainor Åmark', Linda Ekerljung², Bo Lundbäck², Göran Wennergren ${ }^{1}$ \\ From EAACI International Severe Asthma Forum (ISAF 2012) \\ Gothenburg, Sweden. 11-13 October 2012
}

\section{Background}

We have previously reported on the outcome in childhood and adolescence in children with severe wheeze in early life. The aim of the present follow-up was to report on the asthma prevalence and risk factors for asthma in adult age.

\section{Methods}

We have prospectively studied asthma development in 101 children hospitalized due to wheezing before the age of two. The cohort was re-investigated at age 25-29 years and tested for bronchial hyper-responsiveness and allergic sensitization. The response rate at adult age was $81 \%$. The results were compared to a population based aged matched control group $(n=1210)$ recruited from the West Sweden Asthma Study.

\section{Results}

Current asthma was seen in $37 \%(30 / 82)$ and $50 \%$ of these had a moderate to severe asthma. In the control group $10 \%$ reported current asthma (OR 5.3, 95\% CI 3.2-8.9; $\mathrm{p}<0.001)$ and $17 \%$ had wheezing during the last 12 months $(\mathrm{p}<0.001)$. Current use of asthma medication was reported in $31 \%$ of the cohort (of which $66 \%$ used inhaled corticosteroids and/or montelukast), compared to $8 \%$ in the control group ( $\mathrm{p}<0.001)$. Current atopy was found in $54 \%$, with $42 \%$ reporting doctor-diagnosed rhinitis, $11 \%$ current eczema and $16 \%$ food allergy. Among the controls rhinitis was reported in $29 \%(\mathrm{p}=0.013)$ and eczema in $13 \%(\mathrm{~ns})$. Smoking was reported in $30 \%$ of the cohort, compared to $16 \%$ in the control group $(\mathrm{p}=0.002)$.

In the cohort, current allergy (OR 9.7, 95\% CI 3.0-31.1) and female gender (OR 3.2, 1.1-9.5) increased the risk of adult asthma independently of each other. Females with current allergy had the highest risk of adult asthma,

Department of Paediatrics, University of Gothenburg, Sweden

Full list of author information is available at the end of the article compared to males without allergy (OR 29.4, 5.0-173.3). This is illustrated in a stratified Cox regression analysis where the females with current allergy have the lowest chance of recovery (Hazard Ratio 0.2, 95\% CI 0.06-0.5) compared to males without allergy.

\section{Conclusion}

Subjects with severe early wheezing have an increased risk of adult asthma. Females with current allergy had the highest risk of persistent asthma and the lowest chance of recovery.

\section{Author details}

${ }^{1}$ Department of Paediatrics, University of Gothenburg, Sweden. ${ }^{2}$ Krefting Research Centre, Department of Medicine, University of Gothenburg, Sweden.

Published: 3 May 2013

doi:10.1186/2045-7022-3-S1-08

Cite this article as: Goksör et al:: High risk of adult asthma following severe wheeze in early life. Clinical and Translational Allergy 2013 3(Suppl 1):O8.

Submit your next manuscript to BioMed Central and take full advantage of:

- Convenient online submission

- Thorough peer review

- No space constraints or color figure charges

- Immediate publication on acceptance

- Inclusion in PubMed, CAS, Scopus and Google Scholar

- Research which is freely available for redistribution
C 2013 Goksör et al; licensee BioMed Central Ltd. This is an Open Access article distributed under the terms of the Creative Commons Attribution License (http://creativecommons.org/licenses/by/2.0), which permits unrestricted use, distribution, and reproduction in any medium, provided the original work is properly cited. 